\title{
Selective Gonadotrophin Uptake by Mouse Ovarian Carcinoma
}

The ovary of the rodent has been recognized as a target organ for human chorionic gonadotrophin (HCG) for many years $\mathbf{1 , 2}$. In support of the many early studies using nonlabeled HCG, the radiolabeled hormone ${ }^{125} \mathrm{I}-$ HCG) was recently found to concentrate in large amounts in the intact mouse ${ }^{3}$ and rat ${ }^{4}$ ovary. However, the receptor cell for HCG in the rodent ovary has been demonstrated only by indirect methods ${ }^{5}$. The need for an in vivo clone of ovarian cells was apparent for studies encompassing the receptor cell specificity for HCG. It was thought that a functional tumor of a specific ovarian cell type might fulfill the requirements for an in vivo 'pure' cell line. Studies were initiated in which mice bearing either granulosa or theca cell tumors were administered ${ }^{125} \mathrm{I}-\mathrm{HCG}$. Evidence is presented that only the theca cell carcinomas concentrated the radiolabeled gonadotrophin, as will now be described.

Materials and methods. HCG (Antuitrin -S, $1700 \mathrm{IU} / \mathrm{mg}$ ) was radiolabeled ${ }^{6}$ through the courtesy of the Abbott Radiopharmaceutical Laboratories, North Chicago, M11inois. The radiolabeled hormone contained a specific activity of $78.42 \mu \mathrm{Ci} / \mu \mathrm{g}$ and a protein concentration of $3.35 \mathrm{\mu g} / \mathrm{ml}$. Radiolabeled human growth hormone ${ }^{125} \mathrm{I}$ $\mathrm{HGH}$ ) was used as a radiohormone control. The ${ }^{125} \mathrm{I}-\mathrm{HCG}$ was analyzed for immunologic and biologic activity by hemagglutination inhibition ${ }^{7}$ and the Delfs uterine weight. assay ${ }^{8}$, respectively.

Table I. The percent dose uptake per gram of tissue $(\% / g)$ is demonstrated for various organs of radiohormone injected female mice

\begin{tabular}{|c|c|c|c|c|}
\hline \multirow{2}{*}{$\begin{array}{l}\text { Radiohormone } \\
\text { Employed }\end{array}$} & \multicolumn{4}{|c|}{ Tissues studied } \\
\hline & Ovaty & Kidney & Liver & Muscle \\
\hline \multirow{2}{*}{${ }^{125} \mathrm{I}-\mathrm{HCG}(6) \overline{\mathrm{X}}$} & 15.090 & 5.201 & 1.610 & 0.513 \\
\hline & 3.817 & 0.080 & 0.325 & 0.022 \\
\hline \multirow{2}{*}{${ }^{251} \mathrm{I}-\mathrm{HGH}(6) \overline{\mathrm{X}}$} & 1.082 & 3.624 & 1.805 & 0.733 \\
\hline & 0.215 & 0.355 & 0.298 & 0.215 \\
\hline
\end{tabular}

The figures represent the mean $(\bar{X})$ and standard error (SE) of the mean for 6 animal studies each (see parentheses).

Table II. The percent dose uptake per gram of tissue is presented for mice bearing theca and granulosa cell tumors

\begin{tabular}{|c|c|c|c|c|c|}
\hline \multicolumn{2}{|l|}{ Tumor and radiohormone } & \multicolumn{4}{|c|}{ Tissues studied } \\
\hline & & Tumor & Ovary & Liver & Muscle \\
\hline \multirow[t]{2}{*}{${ }^{125}$ Theca (8) I-HCG } & $\bar{X}$ & 11.611 & 8.911 & 2.053 & 0.731 \\
\hline & $\mathrm{SE}$ & 1.630 & 4.077 & 0.244 & 0.122 \\
\hline \multirow[t]{2}{*}{ Granulosa (8) ${ }^{125} \mathrm{I}-\mathrm{HCG}$} & $\overrightarrow{\mathrm{X}}$ & 1.300 & 8.605 & 1.280 & 0.440 \\
\hline & $\mathrm{SE}$ & 0.158 & 1.570 & 0.153 & 0.110 \\
\hline \multirow[t]{2}{*}{ Theca $(8){ }^{125} \mathrm{I}-\mathrm{HGH}$} & $\bar{X}$ & 1.168 & 0.602 & 1.356 & 0.351 \\
\hline & $\mathrm{SE}$ & 0.130 & 0.101 & 0.037 & 0.858 \\
\hline
\end{tabular}

The mice were injected with either ${ }^{125} \mathrm{I}-\mathrm{HCG}$ or ${ }^{125} \mathrm{I}-\mathrm{HGH}$. The figures represent the mean $(\bar{X})$ and standard error (SE) of the mean for 8 animal studies each (see parentheses). HCG, Human chorionic gonadotrophin; $\mathrm{HGH}$, Human growth hormone.
Mice of the A7-(C 57xA) strain bearing either granulosal or theca cell tumors were kindly supplied by Dr. W. U. GARDNER, Dept. of Anatomy, Yale University. The mice were used 2 to 4 months following subcutaneous implantation of the tumors. Both normal and tumor bearing mice received $30-40 \mu \mathrm{Ci}$ of either ${ }^{125} \mathrm{I}-\mathrm{HCG}$ or ${ }^{125} \mathrm{I}-\mathrm{HGH}$ intravenously. Three $\mathrm{h}$ later, the animals were autopsied and 19 tissues were removed, weighed, and assayed for radioactivity in a gamma well-counter. The results were expressed as the percent dose uptake of isotope per gram of tissue $(\% / g)$.

Results and discussion. Both the immunologic and the biologic assays for $\mathrm{HCG}$ demonstrated specific activity of the radiolabeled hormone. The radioisotopic tissue distribution studies were first performed on mature cycling female mice without tumors (Table I). The uptake levels of ${ }^{125}$ I-HCG were significantly higher in the ovary than in any other tissue studied with the exception of the thyroid. The $\% / g$ of ${ }^{125} \mathrm{I}-\mathrm{HCG}$ was 15 times higher in the ovaries than in comparable tissue of control mice injected with ${ }^{125} \mathrm{I}-\mathrm{HGH}$. The radio-uptake levels of $\mathrm{HCG}$ in the kidney were significantly higher than HGH because the former hormone is rapidly excreted by the mammalian kidney. Concomitantly, radioisotope levels in the other organs (such as liver and muscle) were insignificant.

HCG and $\mathrm{HGH}$ radio-uptake levels were compared in mice bearing granulosa and mice bearing theca cell tumors (Table II). The mean $(\overline{\mathrm{X}})$ uptake levels of $\mathrm{HCG}$ in the theca tumors were higher than any other tissue studied including the ovary. The ovary was frequently suppressed by the theca cell tumor, thereby causing the large variation in ovarian uptake as evidenced by the standard error (SE) in Table II. When suppressed, the ovaries were shrunken and appeared yellow (atretic) in color. The kidney uptake levels were similar to the normal female study reported above. All other tissues were unremarkable. In comparing the 2 ovarian tumors, the theca cell type concentrated 125 I-HCG 9 times greater than its granulosa cell counterpart. The mean \%/g level of the ovary in mice bearing granulosa cell tumors was nearly identical to that in mice with theca tumors. However, the SE in the former group was greatly reduced. All other tissue $\% / g$ values were similar among the 2 groups. Mice bearing theca cell tumors were also injected with ${ }^{125}$ I-HGH (Table II). The thecal cell tumors did not concentrate $\mathrm{HGH}$ as their \%/g values were only $1 / 10$ as high in tumors of comparable mice administered ${ }^{125} \mathrm{I}-\mathrm{HCG}$. The uptake of ${ }^{125} \mathrm{I}-\mathrm{HCG}$ in the ovary and tumor were also confirmed by autoradiography.

Data from the present study demonstrated an ovarian tumor cell selectivity for an exogenous gonadotrophin. These studies suggest that the ovarian receptor cell for HCG in the intact (mature, cycling) rodent may be of thecal derivation. The mouse ovarian tumor types

1 S. Aschinim and B. Zondek, Am. J. Obstet. Gynec, 19, 335 (1930).

2 R. W. PAYNe and R. H. Runser, Endocrinology 26, 313 (1958).

3 A. EshKol and B. LunENFELD, in Pharmacology of Hormonal Polypeptides and Proteins (Eds. N. Back, L. Martivi and R. Pooletti; Plenum Press, New York 1968).

4 D. H. Expeland, E. Noftolin and C. A. Paulsen, in Gonadotropins (Ed. E. RosemberG; Geron-x, Los Altos 1968).

5 B. FAlck, K. Menander and O. Nordanstedt, Nature, Lond. 193, 593 (1962)

${ }^{6}$ W. M. Hunter and F. C. Greenwood, Nature, Lond. 194, 495 (1962).

7 W. R. Butr, in The Chemistry of the Gonadotrophins (Charles C. Thomas, Springfield, Ill. 1967).

8 E. DELF, Endocrinology 28, 196 (1941). 
employed in the present study have been previously characterized according to growth pattern and histology by GARDNER ${ }^{9}$. The granulosa (Types I and III) and theca tumors (Type II) described by Gardner were usually composed of at least $70-80 \%$ of the particular cell type designated. In addition, the tumors were functional having been shown to produce estrogen, and to a lesser extent, androgen. It was noted by LI and GARDNER ${ }^{10,11}$ that the ovaries of tumor bearing mice treated with gonadotrophin (pregnant mare serum) showed androgenic effects. The ovarian suppression by the theca cell tumors noted in the present study further attest to the androgenic effects produced by this tumor type. Thus, the histological and endocrine aspects of these tumors are well established.

Previous investigations have implicated the theca cells and their derivatives, the interstitial cells, as an index of HCG sensitivity ${ }^{12}$. In the hypophysectomized rat, $\mathrm{HCG}$ has been reported to exert a powerful stimulating effect on the ovarian interstitial cells ${ }^{2}$. In the intact animal, HCG is known to promote follicular growth and luteinization due to its synergistic activity with the pituitary gonadotrophins ${ }^{13}$. The receptor cell for HCG in the pseudopregnant rat ovary is reportedly the lutein cells of the corpus lutea ${ }^{14}$. Thus, it appears that most of the ovarian cellular constituents are sensitive to HCG stimulation depending on the physiological state of the animal ovary.

The two cell theory of hormone production in the ovary states that the granulosa cells produce one type of steroid, the theca another, and that both are necessary for estrogen production ${ }^{15}$. Recent tissue culture and transplant studies have shown that at least 2 of the ovarian cell types (granulosa + theca or interstitial) must be present in order for estrogen secretion to occur ${ }^{16}$. Thus, steroid production in the ovary is dependent on an interplay between the 2 cell types. The theca and interstitial cells are capable of producing copious amounts of androgenic steroids such as androstenedione and testosterone; these steroids are the immediate precursors of estrogens ${ }^{17}$. It is suggestive, from the present study, that the theca and/or interstitial cells are the major HCG receptor cell in the intact, nonpregnant rodent ovary and ovarian tumor (theca). Perhaps HCG stimulates the theca cells to produce the androgenic precursors which then interact with granulosal cells for the production of estrogens. In the corpus luteum, however, the granulosa cells are transformed into a lutein cell capable of both progesterone and estrogen biosynthesis. The lutein cells become highly sensitive to HCG since they are more capable of producing the androgenic steroid precursors due to the change in the biosynthetic pathway.

Zusammentassung. Bei Mäusen mit Granulosa- oder Theca-Tumoren wurde die Bindung von ${ }^{125} \mathrm{I}-\mathrm{HCG}$ untersucht. Im Vergleich zur Bindung an andere Gewebe derselben Tiere konnte eine zellspezifische Bindung im Beteich der Tumoren festgestellt werden. Die Befunde werden im Zusammenhang mit der Zweizelltheorie der ovariellen Steroidgenese diskutiert.

\section{G. J. Mizejewski}

\section{Department of Biology}

University of South Carolina, Columbia

(South Carolina 29208, USA), and

University of Michigan, Medical Center,

Ann Arbor (Michigan 48105, USA),

24 January 1972.

9 W. U. Gardner, Can. Res. 15, 109 (1955).

10 M. H. Li and W. U. Gardner, Can. Res. 9, 35 (1949).

11 W. U. GARDNER, natn. Câncer Inst. 26, 829 (1961).

12 S. L. Leonard and P. E. Smith, Soc. Proc. exp. Biol. Med. 30, 1248 (1933).

13 R. L. Noble, I. W. Rowlands, M. H. WARWICK and P.C. WiLliams, J. Endocr. 1, 22 (1939).

14 K. Sayard, J. M. Marsh and B. F. Rice, in Recent Progress in Hormone Research (Ed. G. Prncus; Academic Press, New York 1965).

$15 \mathrm{~K}$. Amren, L. Hamberger and L. Rubinstein in The Gonads (Ed. K. W. McKerns; Appleton-Century-Crafts, New York 1969).

${ }^{16}$ A. AakvaAG and $K$. EtK-NES, in The Gonads (Ed. K. W. Mc KERNS; Appleton-Century-Crafts, New York 1969).

12 K. J. RyAN and O. W. SmITH, in Recent Progress in Hormone Research (Ed. G. PINcus; Academic Press, New York 1965).

\section{$\mathrm{N}^{\alpha}$-Carbamoyl-2-O-Methyltyrosine-oxytocin and 1-6 $\alpha$ Deamino Cystathionine-2-O-methyltyrosine Oxytocin: Two Antagonists of Oxytocin on Amphibian Epithelial Cell Receptors}

Several structural analogues of neurohypophyseal hormones have been shown to antagonize the effects of the active peptides on their different target organs (for review, see $^{1}$ ). In the present study, we describe the inhibition of the hydroosmotic and natriferic effects of oxytocin on the frog skin and bladder by $\mathrm{N} \alpha$-Carbamoyl-20-methyltyrosine-oxytocin: $\mathrm{CbmOT}^{2}$ and $1-6 \alpha$ deaminocystathionine-2-O-methyltyrosine-oxytocin: MeDCOT-13; the structure of these analogues ${ }^{4}$ is described in Table 1

Experimental. The hydroosmotic effect (increase in the net water flow along an osmotic gradient) was measured on the isolated frog bladder (Rana esculenta) using a previously described technique ${ }^{5}$. The dose-response relationship for synthetic oxytocin (Syntocinon Sandoz) was first determined using the cumulative doses technique. The affinity of oxytocin for its receptor was measured according to EGGENA ${ }^{6}$ et al. by the $\mathrm{PD}_{2}$ value (negative logarithm of the molar concentration of hormone in the medium (A50) yielding half the maximum response). Its apparent intrinsic activity was measured by the magnitude of the maximum biological response. After washing out the hormone and complete reversal of the hydroosmotic response, the dose-response relationship for oxytocin was again determined in the presence of a known concentration (B) of the inhibitor. The new A 50 value (A 50 B) was used to calculate the affinity constant of the inhibitors:

$$
p A 2=-\log (B /(A 50 B / A 50-1))
$$

I J. Rudinger and I. Krejčí, Handb. exp. Pharmak. 23, 748 (1968). 2 A. Chimiak, K. Eisler, K. Jost and Rudinger, Colln Czech. chern. Commun. 33, 2918 (1968).

${ }^{3} \mathrm{~K}$. Jošt, in preparation.

4 The authors are very much indebted to Dr. K. Jošr for his kind gift of the oxytocin analogues used in this study.

5 J. Bourguet and S. JARD, Biochim. biophys. Acta $8 \&, 442(1964)$

${ }^{8}$ P. Eggena, I. L. Schwartz and R. WaLter, J. gen. Physiol. 52 , 465 (1968). 